\title{
Reproductive disturbances in multiple neuroendocrine tumor syndromes
}

\author{
Aristides Lytras and George Tolis \\ Division of Endocrinology and Metabolism, Hippocrateion General Hospital, Vas. Sofias 108, GR 115-27 Athens, Greece \\ (Correspondence should be addressed to A Lytras; Email: alytras@ontelecoms.gr)
}

\begin{abstract}
In the context of multiple neuroendocrine tumor syndromes, reproductive abnormalities may occur via a number of different mechanisms, such as hyperprolactinemia, increased GH/IGF-1 levels, hypogonadotropic hypogonadism, hypercortisolism, hyperandrogenism, hyperthyroidism, gonadotropin hypersecretion, as well as, tumorigenesis or functional disturbances in gonads or other reproductive organs. Precocious puberty and/or male feminization is a feature of McCune-Albright syndrome (MAS), neurofibromatosis type 1 (NF1), Carney complex (CNC), and Peutz-Jeghers syndrome (PJS), while sperm maturation and ovulation defects have been described in MAS and CNC. Although tumorigenesis of reproductive organs due to a multiple neuroendocrine tumor syndrome is very rare, certain lesions are characteristic and very unusual in the general population. Awareness leading to their recognition is important especially when other endocrine abnormalities coexist, as occasionally they may even be the first manifestation of a syndrome. Lesions such as certain types of ovarian cysts (MAS, CNC), pseudogynecomastia due to neurofibromas of the nipple-areola area (NF1), breast disease (CNC and Cowden disease (CD)), cysts and 'hypernephroid' tumors of the epididymis or bilateral papillary cystadenomas (mesosalpinx cysts) and endometrioid cystadenomas of the broad ligament (von Hippel-Lindau disease), testicular Sertoli calcifying tumors (CNC, PJS) monolateral or bilateral macroochidism and microlithiasis (MAS) may offer diagnostic clues. In addition, multiple neuroendocrine tumor syndromes may be complicated by reproductive malignancies including ovarian cancer in $\mathrm{CNC}$, breast and endometrial cancer in $\mathrm{CD}$, breast malignancies in NF1, and malignant sex-cord stromal tumors in PJS.
\end{abstract}

Endocrine-Related Cancer (2009) 16 1125-1138

\section{Introduction}

Multiple neuroendocrine tumor syndromes may appear in a sporadic mode. The McCune-Albright syndrome (MAS; OMIM \#174 800), a sporadic disease, representing a mosaic case of GNAS gene mutation leading to stimulatory G-protein $\alpha$ subunit $\left(\mathrm{G}_{\mathrm{s}} \alpha\right)$ activation, provides an example of a phenotype associated with a post zygotic gene alteration that is present in multiple but not in all tissues/cells. Mosaicism has been also reported for other syndromes such as the von Hippel-Lindau disease (VHLD; OMIM \#193 300), which is primarily hereditary (Prowse et al. 1997, Murgia et al. 2000).

Hereditary multiple neuroendocrine tumor syndromes include multiple endocrine neoplasia (MEN) type 1, 2A, 2B and 4 (OMIM MEN1:+131 100; MEN2A: \#171 400; MEN2B: \#162 300; MEN4:
\#610 755), Carney complex (CNC; OMIM \#160 980), von Recklinghausen disease (neurofibromatosis type 1, NF1; OMIM + 162 200), VHLD, paraganglioma/ pheochromocytoma syndromes (PGL1, 2, 3, 4; OMIM PGL1: \#168 000; PGL2: \%601 650; PGL3: \#605 373; PGL4: \#115 310).

Hereditary multiple tumor syndromes with limited neuroendocrine involvement include the Peutz-Jeghers syndrome (PJS; OMIM \#175 200) and Cowden disease (CD; OMIM \#158 350).

In the context of multiple tumor syndromes, reproductive abnormalities may occur via a number of different mechanisms. The most frequent etiology is the presence of hyperprolactinemia, which may occur due to direct production by a prolactinoma or a mixed somatolactotrope tumor. MEN1, MAS, and rarely CNC may be accompanied by prolactinomas; however, other 
large nonprolactin (PRL)-producing pituitary adenomas may lead to hyperprolactinemia when pressing on the optic chiasm resulting in stalk compression and blockade of the tonic inhibition of lactotropes by dopamine. Hyperprolactinemia will suppress LH levels and pulsatility, and reverse the LH/FSH ratio resulting in hypogonadotropic hypogonadism. A large pituitary tumor may also result in hypogonadotropic hypogonadism applying mechanical pressure and disrupting gonadotrope function. In addition, gonadotropin hypersecretion due to a LH/FSH-producing adenoma may also be part of pituitary pathology.

Increased GH/insulin-like growth factor-1 (IGF-1) levels due to a GH-secreting pituitary adenoma may lead to insulin resistance and hyperinsulinemia inducing a polycystic ovary syndrome (PCOS) phenotype affecting ovulatory function. Hypercortisolism and/or hyperandrogenism due to a pituitary ACTH adenoma, ectopic production of ACTH or increased cortisol/androgen production by adrenal tumor(s) may result in metabolic disturbances affecting general health and/or reproductive function. Similarly, hyperthyroidism that may result from thyroid toxic adenoma(s) or a pituitary TSH adenoma will affect metabolic status and induce menstrual disturbances and increased rate of first trimester abortions.

Finally, tumorigenesis or functional disturbances in gonads or other reproductive organs complicate more or less frequently these syndromes.

\section{Endocrine hormonal disturbances in the context of a multiple endocrine syndrome}

\section{Pituitary hormones}

Hormonal disturbances are very frequent in multiple endocrine tumor syndromes.

Excess of all pituitary hormones has been described in the context of MEN1. Anterior pituitary adenomas (2/3 of the cases are microadenomas) are most frequently PRL (may be the presenting feature in up to $15 \%$ and may affect up to $35 \%$ of patients in the course of their lives), GH (may be the presenting feature in up to $5 \%$ and may affect up to $12 \%$ of patients in the course of their lives), and ACTH secreting. A few gonadotrope tumors, TSH-secreting adenomas, and a TSH carcinoma have been also reported (Socin et al. 2003, Benito et al. 2005, Sztal-Mazer et al. 2008, Scheithauer et al. 2009). Apart from mono- or plurihormonal pituitary adenomas, ectopic GHRH production may be another hormonal manifestation in MEN1 that may affect pituitary function-stimulating GH secretion by somatotropes (Trouillas et al. 2008).
In MAS, the most usual pituitary abnormalities include GH excess (4-5\% of the cases) and hyperprolactinemia (3-4\% of the cases); however, ACTH- and TSH-secreting tumors have been described (Gessl et al. 1994, Riminucci et al. 2002).

In $\mathrm{CNC}$, increased activity of the $\mathrm{GH}$ axis has been reported in up to $75 \%$ of patients, and pituitary tumors are most often somatotropinomas (10\% of the patients are acromegalic at presentation) with rare cases of prolactinomas (Handley et al. 1992, Stratakis et al. 2001).

In NF1, cases of GH hypersecretion have been attributed to the disruption of the somatostatin tone by optic nerve gliomas (Drake et al. 2000, Drimmie et al. 2000). Central activation of pituitary gonadotrope function, mostly, but not solely, due to the presence of optic pathway tumors or hypothalamic involvement, may induce central precocious puberty in young NF1 patients. In NF1, precocious puberty has been reported in $2.4 \%$ of the patients, while delayed puberty may also occur (Carmi et al. 1999, Virdis et al. 2000, 2003).

\section{Target organ hormones}

Target organ hormone hypersecretion is usually secondary to pituitary hormonal excess; however, in MAS autonomous thyroid, adrenal and gonadal hyperactivity is a much more frequent cause of hormonal overproduction.

In CNC, adrenal and gonadal hyperactivity is quite frequent. Many cases of PJS, MAS and CNC are accompanied by autonomous peripheral steroid hormone hypersecretion and may present with peripheral precocious puberty.

In addition, a rare case of Cushing syndrome caused by a cortisol-producing adrenal adenoma presenting as the first manifestation of MEN1, due to MEN1 gene mutation at a splicing site, has been reported recently (Alzahrani et al. 2008).

Parathyroid hormone (PTH) hypersecretion is mainly a feature of the MEN syndromes, although some cases have been described in NF1 (Altinova et al. 2007, Kodama et al. 2007). PTH-related protein has been implicated as a possible etiologic factor for bone fibrous dysplasia in MAS (Fraser et al. 2000).

A summary of the pituitary and target organ hormonal excess patterns that may occur in the context of multiple neuroendocrine tumor syndromes is presented in Table 1 (Gessl et al. 1994, Drake et al. 2000, Drimmie et al. 2000, Fraser et al. 2000, Riminucci et al. 2002, Socin et al. 2003, Benito et al. 2005, Alzahrani et al. 2008, Scheithauer et al. 2009). 
Table 1 Hormonal excess in multiple tumor syndromes

\begin{tabular}{|c|c|c|c|c|c|c|c|}
\hline & MEN1 & MEN2 & MEN4 & CNC & PJS & NF1 & MAS \\
\hline PRL & 0 & & & 0 & & & 0 \\
\hline $\mathrm{GH}$ & 0 & & 0 & 0 & & 0 & 0 \\
\hline АСТН & 0 & & & & & & 0 \\
\hline FSH/LH & 0 & & & & & 0 & \\
\hline $\mathrm{TSH}$ & 0 & & & $\mathbf{\square}$ & & & 0 \\
\hline $\mathrm{GC}$ & 0 & & & $\overline{0}$ & & & 0 \\
\hline $\mathrm{TH}$ & 0 & & & & & & 0 \\
\hline Estrogen & 0 & & & 0 & 0 & 0 & 0 \\
\hline Androgen & 0 & & & 0 & & 0 & 0 \\
\hline PTH/PTHrP & 0 & 0 & 0 & & & 0 & $\nabla$ \\
\hline
\end{tabular}

, Frequent syndrome feature; $\bigcirc$, rare syndrome feature; $\mathbf{\square}$, in transgenic animal model; $\nabla, \mathrm{PTHrP}$. Estrogen and androgen excess in MEN1 may be observed in women either as a consequence of an FSH adenoma and ovarian hyperstimulation (estrogen excess), or due to acromegaly and increased free androgen levels due to lower steroid hormone-binding globulin (SHBG) levels. In CNC, PJS and MAS peripheral steroid production may be observed. In NF1, usually central precocious puberty is the cause of steroid hormone excess. Elevated secretion of PTHrP has been reported to be possibly associated with bone fibrous dysplasia in MAS. For references, please see text. PRL, prolactin; GC, glucocorticoids; TH, thyroid hormone; PTH, parathyroid hormone; PTHrP, parathyroid hormone-related protein; MEN, multiple endocrine neoplasia; CNC, Carney Complex; PJS, Peutz-Jeghers syndrome; NF1, neurofibromatosis type 1 (von Recklinghausen disease); MAS, McCune-Albright syndrome.

\section{Pathophysiology and clinical presentation of reproductive disturbances in hormone excess}

Hyperprolactinemia, as has been demonstrated almost three decades ago, suppresses LH levels and pulsatility, leading to hypogonadotropism and reversal of the LH/FSH ratio (Tolis 1980). As a result, patients may present with amenorrhea, galactorrhea, infertility, or impotence in males.

Aside from PRL excess, GH hypersecretion also affects menstrual cyclicity. Menstrual disturbances may be the first manifestation of acromegaly, while menstrual irregularity may affect $40-84 \%$ of female patients in the course of the disease (Kaltsas et al. 1999). A small percentage of patients present with impotence or loss of libido. In an analysis of 47 women with acromegaly, patients with menstrual irregularity had a greater impairment of anterior pituitary function (Kaltsas et al. 1999). The extent of coexisting PRL hypersecretion and impairment of pituitary function dictates the extent of menstrual disturbance. PRL levels in excess of $1000 \mathrm{mU} / 1$ (normal $<400 \mathrm{mU} / \mathrm{l}$ ) were found in 16 out of the 38 patients with menstrual irregularity compared with 1 out of 9 patients with normal cycles. In addition, amenorrheic patients had higher GH levels, were mainly estrogen deficient, and tended to have larger tumors than patients with normal cycles. In contrast, estrogen-sufficient (estradiol $\left(\mathrm{E}_{2}\right)$ $>140 \mathrm{pmol} / \mathrm{l}$ ) acromegalic patients had clinical baseline endocrine profiles and $\mathrm{LH}$ responses to GnRH stimulation similar to those in patients with PCOS. An independent inverse correlation between $\mathrm{GH}$ and sex hormone-binding globulin (SHBG) levels suggested to the authors that GH may directly or indirectly lead to a fall in SHBG (possibly attributed to the hyperinsulinemia of acromegaly). As concluded by the authors, low SHBG levels may contribute to the menstrual disturbance seen in acromegaly in addition to any gonadotropin deficiency or hyperprolactinemia, and may account for hirsutism in the presence of normal testosterone levels (Kaltsas et al. 1999).

Gonadotropin hypersecretion due to a gonadotrope adenoma is rare among patients with multiple neuroendocrine tumor syndromes. In general, gonadotrope tumors may be complicated by ovarian hyperstimulation even in the absence of continually elevated FSH levels (Kihara et al. 2006). In a 40-year-old woman with a FSH-producing pituitary microadenoma, the serum concentration of $\mathrm{E}_{2}$ and the size of her multicystic ovaries fluctuated dramatically and were transiently normalized (Maruyama et al. 2005). In this patient, ovarian hyperstimulation syndrome developed in spite of 'normal' FSH levels and although FSH bioactivity, as estimated by the serum FSH bioactivity/immunoactivity ratio, appeared normal (Kajitani et al. 2008).

A characteristic case of a woman with MEN1 and a gonadotrope tumor has been described (Benito et al. 2005). She originally presented with amenorrhea and was treated at age 31 by transsphenoidal surgery, which was repeated 5 years later. Elevated plasma $\mathrm{E}_{2}(>1840 \mathrm{pmol} / \mathrm{l})$ and endometrial hyperplasia persisted after the second transsphenoidal surgery. At the age of 39, ovarian stimulation, multiple ovarian cysts, and endometrial hyperplasia were observed as a result of persistent mild elevation of plasma FSH (approximately twofold higher than the upper limit of 
normal $(2 \times \mathrm{ULN}))$ and markedly elevated plasma $\mathrm{E}_{2}$ concentrations (Djerassi et al. 1995). She subsequently developed hyperparathyroidism, while later a temporal lobe metastasis indicated that the tumor was a gonadotrope carcinoma (Benito et al. 2005).

However, in a woman with a gonadotrope tumor, the extent of reproductive disturbances is dependent on the remaining pituitary function and the presence of sufficient pituitary LH production capable of supporting estrogen secretion by the ovary. High PRL and $\mathrm{E}_{2}$, and low LH occur in most cases, although $\mathrm{E}_{2}$ may remain within normal limits for the corresponding menstrual cycle phases. However, in cases with essentially absent LH, the ovarian hyperstimulation profile associated with a FSH-secreting adenoma is not accompanied by high estrogen levels and endometrial hyperplasia. As an example, in a 28 -year-old woman with abdominal pain and large ovaries with multiple follicular cysts, a FSH-secreting pituitary macroadenoma (not in the context of a MEN1 phenotype) was not accompanied by high levels of serum $\mathrm{E}_{2}$, probably due to insufficient LH production (Shimon et al. 2001).

In a man with MEN1, a FSH-secreting gonadotrope macroadenoma encircling both carotid arteries and compressing the optic chiasm was accompanied by reduced libido and erectile function in the presence of a typical hormonal profile with high FSH $(\sim 3 \times \mathrm{ULN})$ and $\alpha$-subunit, moderately high PRL, and normal LH in spite of low total testosterone (Sztal-Mazer et al. 2008).

\section{Fertility, gestation, parturition, and postdelivery health issues of mother, fetus, and newborn}

Hyperthyroidism, hypercortisolism, hyperandrogenism, and hyperparathyroidism have been associated with severe adverse effects on fertility, pregnancy progression, and pregnancy outcome. Maternal hyperthyroidism, especially when poorly controlled, is associated with an increased risk of miscarriage, medically indicated preterm delivery, preeclampsia, congestive heart failure, thyroid storm, intrauterine growth retardation, low birth weight or fetal loss and stillbirth (Abalovich et al. 2007). Women with hyperandrogenism and PCOS, apart from subfertility, have a significantly higher risk of developing gestational diabetes, pregnancy-induced hypertension, preeclampsia and preterm birth, risk of neonatal intensive care unit admission, and perinatal mortality (Boomsma et al. 2006, Martin et al. 2008). Hypercortisolism is associated with maternal and fetal morbidity and/or mortality including hypertension, gestational diabetes or impaired glucose tolerance, impaired wound healing, osteoporosis, bone fractures, psychiatric complications, maternal cardiac failure, premature birth, stillbirth, intrauterine deaths, or spontaneous abortions (Bronstein et al. 2002, Lindsay \& Nieman 2005). Hyperparathyroidism may result in hypercalcemic crisis of the mother during pregnancy and neonate hypocalcemia, especially when hyperparathyroidism has been undiagnosed (Higgins \& Hisley 1988, Hsieh et al. 1998, Schnatz \& Thaxton 2005, Pieringer et al. 2007).

\section{Tumorigenesis, hyperplasia, architectural, or functional disturbances in reproductive organs in the context of a multiple endo- crine tumor syndrome}

In everyday practice, tumorigenesis of reproductive organs due to a multiple tumor syndrome is rare. However, certain lesions appear characteristic, and the occurrence of unusual types of tumors in patients with other known endocrine abnormalities may occasionally point at the direction of a multiple endocrine tumor syndrome.

Summaries of male and female reproductive organ tumors that may occur in the context of multiple neuroendocrine tumor syndromes are presented in Tables 2 and 3.

\section{Multiple endocrine neoplasia syndrome-1}

The presence of uterine leiomyomas has been described in a number of female MEN1 patients. Uterine smooth muscle tumors have been linked with loss of heterozygosity in $11 \mathrm{q} 13$, i.e. the locus that contains the MEN1 gene (McKeeby et al. 2001), and recently to a new mutation of the MEN1 gene, in a case also manifesting a bladder leiomyoma (Choi et al. 2008). Other genitourinary leiomyomas, such as the case of a ureteral leiomyoma causing hydronephrosis (Ikota et al. 2004), have also been described in MEN1 patients. However, due to the high frequency of these lesions in the general population, their presence does not offer any diagnostic help unless they coexist with other tumors. Regardless, the possible coexistence of leiomyomas should be considered in female MEN1 patients.

A case of an ovarian gastrinoma has also been described in a MEN1 patient, while carcinoids of the ovary have been reported in MEN1 and MEN2A cases (Abboud et al. 2001, Papageorgiou \& Stratakis 2002).

Interestingly, heterozygous MEN1 mutant mice show a high incidence of gonadal tumors of endocrine 
Table 2 Male reproductive organ involvement in multiple tumor syndromes

\begin{tabular}{|c|c|c|c|c|c|}
\hline & MEN & CNC & PJS & MAS & VHLD \\
\hline $\begin{array}{l}\text { Testicular Sertoli } \\
\text { cells }\end{array}$ & & $\begin{array}{l}\text { Large-cell calcifying } \\
\text { tumors }\end{array}$ & $\begin{array}{l}\text { Bilateral multicentric } \\
\text { tumors (most } \\
\text { calcifying) }\end{array}$ & $\begin{array}{l}\text { Isolated mono/ } \\
\text { bilateral testicular } \\
\text { enlargement }\end{array}$ & \\
\hline $\begin{array}{l}\text { Testicular Leydig } \\
\text { cells }\end{array}$ & $\begin{array}{l}\text { Leydig cell tumors } \\
\text { (MEN1 animal } \\
\text { models) }\end{array}$ & Leydig cell tumors & & Leydig cell tumors & \\
\hline $\begin{array}{l}\text { Other testicular } \\
\text { involvement }\end{array}$ & $\begin{array}{l}\text { Testicular cancer in } \\
\text { MEN4? }\end{array}$ & $\begin{array}{l}\text { Adrenocortical rest } \\
\text { tumors }\end{array}$ & & $\begin{array}{l}\text { Interstitial cell } \\
\text { tumors } \\
\text { Testicular } \\
\text { microlithiasis }\end{array}$ & \\
\hline \multirow[t]{2}{*}{$\begin{array}{l}\text { Other male organ } \\
\text { involvement }\end{array}$} & $\begin{array}{l}\text { Prostate } \\
\text { neuroendocrine } \\
\text { tumors and carci- } \\
\text { noids (MEN2B) }\end{array}$ & & & & $\begin{array}{l}\text { Cysts and 'hyper- } \\
\text { nephroid' tumors } \\
\text { of epididymis }\end{array}$ \\
\hline & $\begin{array}{l}\text { Aggressive prostate } \\
\text { cancer 11q13.1 } \\
\text { gain (MEN1 } \\
\text { gene?) }\end{array}$ & & & & $\begin{array}{l}\text { Bilateral papillary } \\
\text { cystadenomas of } \\
\text { epididymis }\end{array}$ \\
\hline
\end{tabular}

origin, i.e. Leydig cell tumors and ovary sex-cord stromal cell tumors (Bertolino et al. 2003, Biondi et al. 2004, Loffler et al. 2007), although such tumors have not been associated with MEN1 in humans. However, testicular cancer may prove in the future to be a feature of the recently described MEN4 syndrome, which is closely related to the MEN1 phenotype but it is attributed to a different genomic defect, i.e. cyclindependent kinase inhibitor 1B mutation. Unfortunately, due to lack of available samples, confirmatory gene analysis was not performed in the case of a deceased 28-year-old MEN4 family member with testicular cancer (Pellegata et al. 2006).

Prostate neuroendocrine tumors and carcinoids have been described in MEN2B, including cases of very young patients (Whelan et al. 1995, Goulet-Salmon et al. 2004).

An 11q13.1 locus gain has been detected in aggressive prostate cancers; however, the significance of this finding and the possibility of any association with the MEN1 syndrome are still under investigation (Paris et al. 2009).

Breast disease in MEN syndromes includes breast cancer, including a few case reports of MEN2 patients (Lima \& Smith 1971, Nozawa et al. 2004) and the frequent occurrence of mammary gland carcinomas in older MEN1 mutant animals (Bertolino et al. 2003); however, a suspected association of MEN1 with breast malignancy remains unproven (Honda et al. 2004, Pal et al. 2009). However, breast metastasis of a pancreatic neuroendocrine carcinoma in a patient with MEN1 has been reported (Treilleux et al. 1997).

\section{McCune-Albright syndrome}

In MAS, large ovarian cysts producing estrogen (as a result of $\mathrm{G}_{\mathrm{s}} \alpha$ activation in ovarian cells) are responsible for the episodic increases in serum estrogen levels and a parallel reduction in gonadotropin secretion. Very frequently, these changes result in sexual precocity. Precocious puberty is part of the characteristic triad of MAS that also includes cafe au lait spots and polyostotic fibrous dysplasia. Autonomous ovarian function persists during puberty and early adult life. Precocious puberty is less frequent in males occurring in $\sim 15 \%$ of the patients (de Sanctis et al. 2003, Matarazzo et al. 2006).

Secondary central precocious puberty following exposure to the peripherally derived sex steroids and responding to therapy with $\mathrm{GnRH}$ analogs has been suggested to occur in a subgroup of patients with MAS (Schmidt \& Kiess 1998).

As the ovarian cysts develop in very young girls prior to the diagnosis of MAS, some of these patients are subjected to oophorectomy for presumed ovarian tumors. A recent study that assessed medical records of an 18-year period (1988-2005) revealed that four out of nine MAS female patients with sudden onset of vaginal bleeding at an age range of 6 months to 7 years underwent salpingo-oophorectomy before the first diagnosis of MAS. Histology revealed benign ovarian cysts in these four patients (Nabhan et al. 2007).

As in many MAS patients, the ovaries may be unequally affected, due to the mosaic distribution of GNAS mutation, and this may offer the possibility of therapeutic intervention. Follow-up of a 33-year-old 


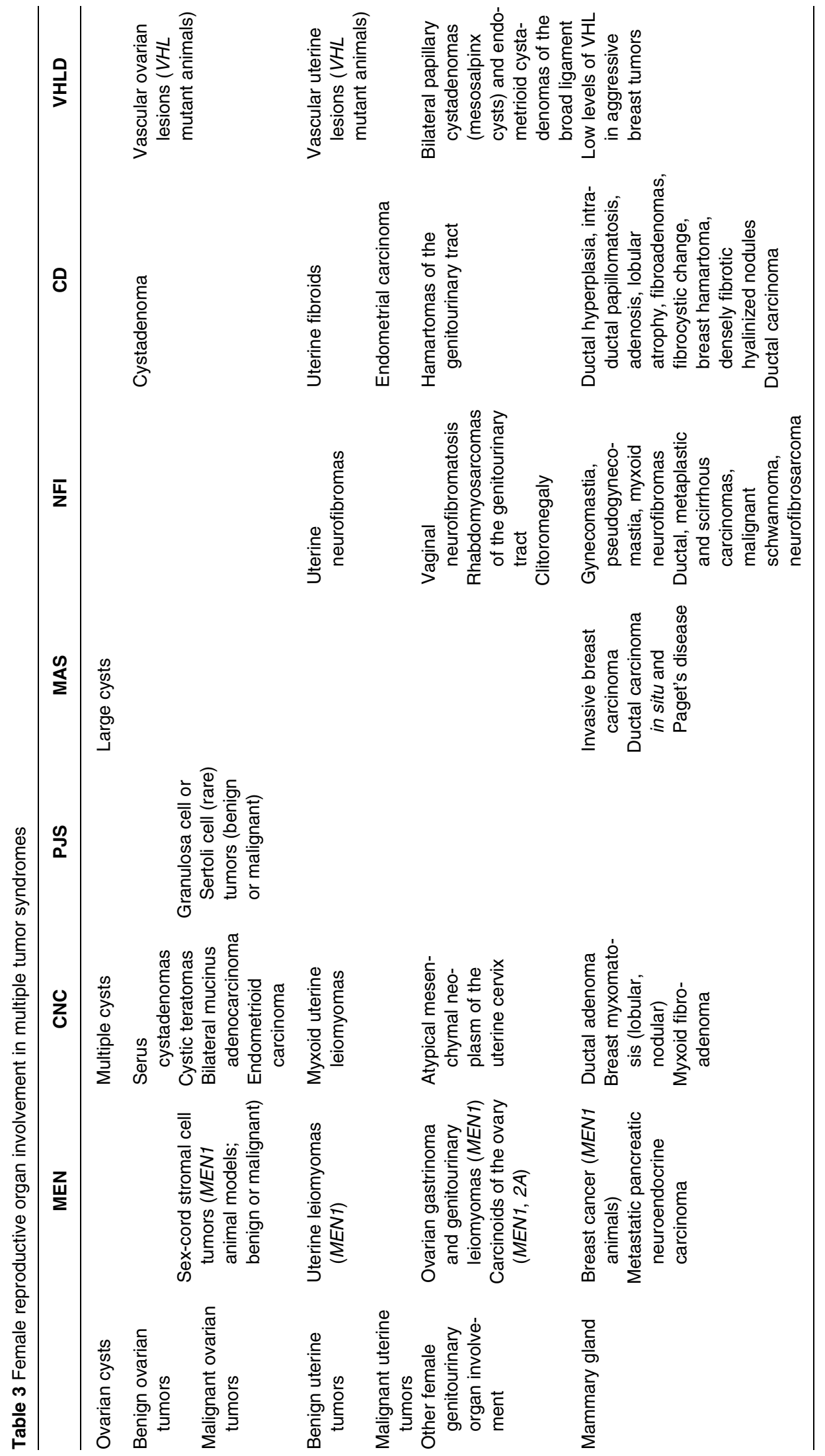


MAS patient (with irregular menstrual cycles of 30-180 days, monophasic temperature curves, and severe pelvic pain) with transvaginal ultrasound and blood tests, at 3-day intervals for 3 months, indicated a persistently quiescent left ovary, a persistently polycystic right ovary, constantly high $\mathrm{E}_{2}$, and very low FSH and LH levels. A regular monthly menstrual cycle was restored soon after right ovariectomy, in spite of the fact that GNAS1 gene mutation was present in both ovaries, as documented by bilateral biopsies (Lavoué et al. 2008). In addition, even in cases where both ovaries appear morphologically affected, a therapeutic approach may be suitable. In a characteristic case report, the least affected ovary of a MAS patient became quiescent with GnRH agonist-induced gonadotropin suppression. Normal ovulation resumed after removal of the affected right ovary and a pregnancy occurred within 3 months reaching term without complications. DNA analysis showed no GNAS mutation in the placenta, umbilical cord structures, or umbilical cord blood indicating an unaffected offspring (Laven et al. 2004).

In male patients, testicular involvement may result in different profiles depending on the extent of $G_{s} \alpha$ activation in Sertoli and Leydig cells. Thus, isolated nonsecretory Sertoli cell defect may present with mono- or bilateral macroorchidism without precocious puberty (Coutant et al. 2001, Arrigo et al. 2006, Rey et al. 2006). If a Leydig cell defect is present, androgen secretion occurs and precocious puberty appears in about $15 \%$ of male patients. Interstitial cell tumors are rare among MAS patients, while testicular microlithiasis has been suggested to be characteristic feature in this syndrome (Wasniewska et al. 2004, 2006).

Interestingly, despite long-term FSH suppression and a very low sperm count, spermatogenesis was active in a 18-year-old MAS patient who first presented with sexual precocity, monolateral macroorchidism, increased testosterone levels, and suppressed gonadotropins 15 years earlier (De Luca et al. 2008).

Breast cancer and a case of a 27-year-old woman with ductal carcinoma in situ and Paget's disease of the nipple have been reported, and it has been suggested that MAS patients may be at an increased risk for breast cancer possibly associated with estrogen hypersecretion and/or GH excess (Tanabe et al. 1998, Huston \& Simmons 2004, Dumitrescu \& Collins 2008).

\section{Carney complex}

In the context of $\mathrm{CNC}$, frequent female reproductive organ manifestations include ovarian benign or malignant tumors (such as serus cystadenomas, cystic teratomas, mucinus adenocarcinomas, endometrioid carcinomas) and myxoid uterine leiomyomas, while an atypical mesenchymal neoplasm of the uterine cervix has also been reported (Nwokoro et al. 1997, Stratakis et al. 2000, Papageorgiou \& Stratakis 2002).

Male reproductive organ manifestations include testicular large-cell calcifying Sertoli cell tumors (LCCSCT), Leydig cell tumors (LCT), and adrenocortical rest tumors of the testes (Carney et al. 1985). Androgen secreting LCT or LCCSCT may cause precocious puberty in boys, while LCCSCT tumors may also be estrogen secreting occasionally accompanied by male feminization (Stratakis et al. 2001, Brown et al. 2007). Apart from the tumorigenesis aspects, recent data suggest that sperm abnormalities are present in CNC. Male mice heterozygous for the protein kinase A type 1- $\alpha$ regulatory subunit (PRKAR1A) gene have severely reduced fertility, and these mice, as well as, CNC patients heterozygous for PRKAR1A mutations have morphologically abnormal sperm and reduced sperm number. This is likely due to elevated protein kinase A catalytic activity in male meiotic or postmeiotic germ cells leading to structural defects in mature sperm explaining the reduced transmission of PRKAR1A inactivating mutations by male patients with CNC. In light of these observations, male subfertility or infertility should be considered in the context of CNC (Burton et al. 2006, Wieacker et al. 2007).

Breast tissue characteristic lesions in CNC include lobular or nodular myxomatosis, myxoid fibroadenomas, and ductal adenomas (Carney \& Toorkey 1991a,b, Courcoutsakis et al. 1997).

\section{Neurofibromatosis type 1}

In NF1 vaginal neurofibromatosis, rhabdomyosarcomas of the genitourinary tract and clitoromegaly are rare manifestations (Griebel et al. 1991, Sutphen et al. 1995, Sharma et al. 2004, Lisewski et al. 2006, Baulies et al. 2008).

In addition, there are several case reports describing the presence of reproductive organ (ovarian and uterine) neurofibromas, which, however, do not always appear associated with other manifestations of neurofibromatosis (Horyn et al. 1988, Gersell \& Fulling 1989, Nortier et al. 1989, Gordon et al. 1996, Nunes et al. 2005, Wei et al. 2005). Whether some of these cases represent manifestations of a distinct entity (rather a result of a somatic or mosaic defect) is not known.

Breast disease includes either true gynecomastia, a rather frequent finding among NF1 patients associated with precocious puberty, or pseudogynecomastia associated with neurofibromas, mainly of the 
nipple-areolar complex (Lipper et al. 1981, Sherman \& Smith 1981, Damiani \& Eusebi 2001, Millman \& Mercado 2004, Murat et al. 2004, Cho et al. 2008). A patient case manifesting myxoid neurofibromas has been reported as well (Gokalp et al. 2007).

Increased relative risk for breast malignancy (by approximately fivefold) has been reported in female NF1 patients (Sharif et al. 2007). Ductal, scirrhous, and metaplastic carcinomas, as well as Paget's disease of the breast, malignant schwannoma, and neurofibrosarcoma, have been described in patients with NF1 who appear to manifest rather unusual breast malignancies compared with the general population (Cox \& Hudson 1956, Malas et al. 1995, Nakamura et al. 1998, Murayama et al. 1999, Güran \& Safali 2005, Kawawa et al. 2007, Natsiopoulos et al. 2007, Invernizzi et al. 2008). A case of male adenocarcinoma and bilateral ductal in situ carcinomas have also been reported (Ronchese 1953, Wilson et al. 2004).

\section{von Hippel-Lindau disease}

In VHLD, characteristic reproductive organ features include epididymal cysts, bilateral papillary cystadenomas and 'hypernephroid' tumors, as well as bilateral papillary cystadenomas (mesosalpinx cysts) and endometrioid cystadenomas of the broad ligament (the developmental equivalent of epididymis in females; Nicolaij et al. 1979, Gruber et al. 1980, Witten et al. 1985, Gersell \& King 1988, Zbar et al. 1999, Shen et al. 2000, Aydin et al. 2005, Mehta et al. 2007).

Vascular ovarian and uterine lesions, including angiectasia, angiomas and hemangiosarcomas, have been observed in a heterozygous VHL mutant animal model of carcinogen exposure (Kleymenova et al. 2004).

Interestingly, low levels of VHL have been detected in cases of aggressive breast tumors (not associated with VHLD and with negative mutation and loss of heterozygosity analysis), suggesting a defect that results in disruption of the normal VHL expression pattern (Sourvinos et al. 2001, Zia et al. 2007). Whether the VHL defect in VHLD patients may contribute to breast cancer progression is presently unknown.

\section{Peutz-Jeghers syndrome}

In PJS, bilateral multicentric Sertoli cell testicular tumors (most calcifying) in boys have been found in cases of rapid growth and advanced bone age associated with markedly elevated serum levels of $E_{2}$ and gynecomastia/feminization. High aromatase activity is responsible for the oversecretion of estrogen by these tumors (Coen et al. 1991, Young et al. 1995, Lefevre et al. 2006).
The occurrence of ovarian granulosa cell tumors is much more frequent than that of testicular tumors, and the appearance of isosexual precocity in girls with PJS is consistent with the production of estrogen by these tumors (Solh et al. 1983). Ovarian Sertoli cell tumors may also develop rarely (Ferry et al. 1994, Zung et al. 1998).

\section{Cowden disease}

Hamartomas of the genitourinary tract, uterine fibroids, and endometrial carcinoma have been reported, while only few patients with $C D$ have ovarian disease, such as ovarian cystadenomas (Papageorgiou \& Stratakis 2002, Scheper et al. 2006, Blumenthal \& Dennis 2008).

Regarding breast disease, typical lesions include mammary ductal hyperplasia, intraductal papillomatosis, adenosis, lobular atrophy, fibroadenomas, fibrocystic change, breast hamartoma, densely fibrotic hyalinized nodules, as shown by a detailed study of 19 women with CD. Among these patients, evidence of breast hamartoma was found in 17 and of malignancy, mainly ductal carcinoma, in 14 out of 19 women (Schrager et al. 1998). Male breast cancer has also been reported (Fackenthal et al. 2001).

\section{Paraganglioma/pheochromocytoma syndromes}

In general, PGL syndromes are not associated with reproductive organ involvement. However, a number of case reports describe the presence of ovarian and vaginal paragangliomas, although no linkage to the PGL syndromes has been documented for these cases, as no SDH gene mutations have been detected (Hassan et al. 2003, Kuscu et al. 2005, McCluggage \& Young 2006, Bacha et al. 2007).

Interestingly, a recent report raises the possibility of contribution of SDH mutations to the development of breast cancer (as well as thyroid and renal cancers) in PTEN-negative Cowden or Cowden-like disease (Ni et al. 2008). This may suggest that PGL patients could be at an increased susceptibility for breast cancer, dependent on their overall genetic background.

\section{Conclusions}

In multiple neuroendocrine tumor syndromes, reproductive function is affected by various mechanisms. Pituitary surgery may lead to partial or complete pituitary insufficiency. In addition, apart from the frequent menstrual cycle abnormalities, tumors and/or cystic lesions may complicate reproductive organs (ovary, uterus, breast, epididymis, testis). Heart and 
other nonreproductive organ involvement may further compromise fertility and/or pregnancy outcome. Prior GH excess (MEN, CNC, MAS) may have affected heart architecture and compromise function, while heart myxomas in $\mathrm{CNC}$ may pose a problem requiring surgical therapy.

A pregnancy in a patient with a multiple tumor syndrome is a complex challenge. The presence of a pituitary adenoma or a pheochromocytoma poses a threat for a successful pregnancy and delivery. Mother and fetal/offspring safety concerns, genetic counseling issues, and doctor responsibility as well as social issues are in question.

Pheochromocytomas or paragangliomas in pregnant MEN, NF1, VHLD, and PGL patients require careful evaluation and design of surgical and medical treatment (Hopkins et al. 1989, Joffe et al. 1993, Hamilton et al. 1997, Demiraran et al. 2001, Kariya et al. 2005).

Hyperthyroidism (MAS), hypercortisolism, hyperandrogenism or GH excess (MEN, CNC, MAS), and hyperparathyroidism (MEN) may cause maternal and fetal morbidity and mortality, including a higher rate of spontaneous abortions, preterm birth or stillbirth, metabolic imbalance (e.g. gestational diabetes or bone loss), maternal hypertension, maternal hypercalcemic crisis, or neonate hypocalcemia.

In addition, in NF1, a high rate of first trimester spontaneous abortions and cesarean sections is associated with maternal manifestations, including neurofibromas or bone abnormalities of the pelvis, skeletal deformities, pheochromocytoma, or spinal cord fibromas.

In CNC, abnormal sperm maturation appears directly associated with the PRKAR1A gene defect; thus, questions, such as, the chronic effects of hormonal excess and/or the significance of genomic defects for the structure and function of reproductive organs in the spectrum of multiple tumor syndromes remain to be answered.

\section{Declaration of interest}

The authors declare that there is no conflict of interest that could be perceived as prejudicing the impartiality of the research reported.

\section{Funding}

This work did not receive any specific grant from any funding agency in the public, commercial, or not-for-profit sector.

\section{References}

Abalovich M, Amino N, Barbour LA, Cobin RH, De Groot LJ, Glinoer D, Mandel SJ \& Stagnaro-Green A 2007

Management of thyroid dysfunction during pregnancy and postpartum: an Endocrine Society Clinical Practice Guideline. Journal of Clinical Endocrinology and Metabolism 92 S1-S47.

Abboud P, Bart H, Mansour G, Pinteaux A \& Birembaut P 2001 Ovarian gastrinoma in multiple endocrine neoplasia type I: a case report. American Journal of Obstetrics and Gynecology 184 237-238.

Altinova AE, Toruner F, Cimen AR, Karakoc A, Atasever T, Yetkin I, Ayvaz G, Cakir N \& Arslan M 2007 The association of neurofibromatosis, bilateral pheochromocytoma and primary hyperparathyroidism. Experimental and Clinical Endocrinology and Diabetes 115 468-470.

Alzahrani AS, Al-Khaldi N, Shi Y, Al-Rijjal RA, Zou M, Baitei EY \& Amin T 2008 Diagnosis by serendipity: Cushing syndrome attributable to cortisol-producing adrenal adenoma as the initial manifestation of multiple endocrine neoplasia type 1 due to a rare splicing site MEN1 gene mutation. Endocrine Practice 14 595-602.

Arrigo T, Pirazzoli P, De Sanctis L, Leone O, Wasniewska M, Messina MF \& De Luca F 2006 McCune-Albright syndrome in a boy may present with a monolateral macroorchidism as an early and isolated clinical manifestation. Hormone Research 65 114-119.

Aydin H, Young RH, Ronnett BM \& Epstein JI 2005 Clear cell papillary cystadenoma of the epididymis and mesosalpinx: immunohistochemical differentiation from metastatic clear cell renal cell carcinoma. American Journal of Surgical Pathology 29 520-523.

Bacha D, Mrad K, Dhouib R, Driss M, Abbes I, Sassi S \& Ben Romdhane K 2007 Paraganglioma: report of a rare case with ovarian involvement. Pathologica 99 50-53.

Baulies S, Cusidó MT, Grases PJ, Ubeda B, Pascual MA \& Fábregas R 2008 Neurofibroma of the vaginal wall. Clinical and Experimental Obstetrics and Gynecology 35 140-143.

Benito M, Asa SL, Livolsi VA, West VA \& Snyder PJ 2005 Gonadotroph tumor associated with multiple endocrine neoplasia type 1. Journal of Clinical Endocrinology and Metabolism 90 570-574.

Bertolino P, Tong WM, Galendo D, Wang ZQ \& Zhang CX 2003 Heterozygous Men 1 mutant mice develop a range of endocrine tumors mimicking multiple endocrine neoplasia type 1. Molecular Endocrinology 17 1880-1892.

Biondi CA, Gartside MG, Waring P, Loffler KA, Stark MS, Magnuson MA, Kay GF \& Hayward NK 2004 Conditional inactivation of the MEN1 gene leads to pancreatic and pituitary tumorigenesis but does not affect normal development of these tissues. Molecular and Cellular Biology 24 3125-3131.

Blumenthal GM \& Dennis PA 2008 PTEN hamartoma tumor syndromes. European Journal of Human Genetics 16 1289-1300. 
Boomsma CM, Eijkemans MJ, Hughes EG, Visser GH, Fauser BC \& Macklon NS 2006 A meta-analysis of pregnancy outcomes in women with polycystic ovary syndrome. Human Reproduction Update 12 673-683.

Bronstein MD, Salgado LR \& de Castro Musolino NR 2002 Medical management of pituitary adenomas: the special case of management of the pregnant woman. Pituitary 5 99-107.

Brown B, Ram A, Clayton P \& Humphrey G 2007 Conservative management of bilateral Sertoli cell tumors of the testicle in association with the Carney complex: a case report. Journal of Pediatric Surgery 42 E13-E15.

Burton KA, McDermott DA, Wilkes D, Poulsen MN, Nolan MA, Goldstein M, Basson CT \& McKnight GS 2006 Haploinsufficiency at the protein kinase A RI $\alpha$ gene locus leads to fertility defects in male mice and men. Molecular Endocrinology 20 2504-2513.

Carmi D, Shohat M, Metzker A \& Dickerman Z 1999 Growth, puberty, and endocrine functions in patients with sporadic or familial neurofibromatosis type 1: a longitudinal study. Pediatrics 103 1257-1262.

Carney JA \& Toorkey BC 1991a Myxoid fibroadenoma and allied conditions (myxomatosis) of the breast. A heritable disorder with special associations including cardiac and cutaneous myxomas. American Journal of Surgical Pathology 15 713-721.

Carney JA \& Toorkey BC $1991 b$ Ductal adenoma of the breast with tubular features. A probable component of the complex of myxomas, spotty pigmentation, endocrine overactivity, and schwannomas. American Journal of Surgical Pathology 15 722-731.

Carney JA, Gordon H, Carpenter PC, Shenoy BV \& Go VL 1985 The complex of myxomas, spotty pigmentation, and endocrine overactivity. Medicine 64 270-283.

Cho YR, Jones S \& Gosain AK 2008 Neurofibromatosis: a cause of prepubertal gynecomastia. Plastic and Reconstructive Surgery $12134 \mathrm{e}-40 \mathrm{e}$.

Choi H, Kim S, Moon JH, Lee YH, Rhee Y, Kang ES, Ahn CW, Cha BS, Lee EJ, Kim KR et al. 2008 Multiple endocrine neoplasia type 1 with multiple leiomyomas linked to a novel mutation in the MEN1 gene. Yonsei Medical Journal 49 655-661.

Coen P, Kulin H, Ballantine T, Zaino R, Frauenhoffer E, Boal D, Inkster S, Brodie A \& Santen R 1991 An aromataseproducing sex-cord tumor resulting in prepubertal gynecomastia. New England Journal of Medicine 324 317-322.

Courcoutsakis NA, Chow CK, Shawker TH, Carney JA \& Stratakis CA 1997 Syndrome of spotty skin pigmentation, myxomas, endocrine overactivity, and schwannomas (Carney complex): breast imaging findings. Radiology 205 221-227.

Coutant R, Lumbroso S, Rey R, Lahlou N, Venara M, Rouleau S, Sultan C \& Limal JM 2001 Macroorchidism due to autonomous hyperfunction of Sertoli cells and
$\mathrm{G}(\mathrm{s}) \alpha$ gene mutation: an unusual expression of McCuneAlbright syndrome in a prepubertal boy. Journal of Clinical Endocrinology and Metabolism 86 1778-1781.

Cox TR \& Hudson LH 1956 Simultaneous neurofibrosarcoma of the breast and back in von Recklinghausen's disease. American Journal of Surgery 92 476-479.

Damiani S \& Eusebi V 2001 Gynecomastia in type-1 neurofibromatosis with features of pseudoangiomatous stromal hyperplasia with giant cells. Report of two cases. Virchows Archiv 438 513-516.

Demiraran Y, Ozgön M, Utku T \& Bozkurt P 2001 Epidural anaesthesia for Caesarean section in a patient with von Hippel-Lindau disease. European Journal of Anaesthesiology 18 330-332.

Djerassi A, Coutifaris C, West VA, Asa SL, Kapoor SC, Pavlou SN \& Snyder PJ 1995 Gonadotroph adenoma in a premenopausal woman secreting follicle-stimulating hormone and causing ovarian hyperstimulation.

Journal of Clinical Endocrinology and Metabolism 80 591-594.

Drake AJ, Lowis SP, Bouffet E \& Crowne EC 2000 Growth hormone hypersecretion in a girl with neurofibromatosis type 1 and an optic nerve glioma: resolution following chemotherapy. Hormone Research 53 305-308.

Drimmie FM, MacLennan AC, Nicoll JA, Simpson E, McNeill E \& Donaldson MD 2000 Gigantism due to growth hormone excess in a boy with optic glioma. Clinical Endocrinology 53 535-538.

Dumitrescu CE \& Collins MT 2008 McCune-Albright syndrome. Orphanet Journal of Rare Diseases 312.

Fackenthal JD, Marsh DJ, Richardson AL, Cummings SA, Eng C, Robinson BG \& Olopade OI 2001 Male breast cancer in Cowden syndrome patients with germline PTEN mutations. Journal of Medical Genetics 38 159-164.

Ferry JA, Young RH, Engel G \& Scully RE 1994 Oxyphilic Sertoli cell tumor of the ovary: a report of three cases, two in patients with the Peutz-Jeghers syndrome. International Journal of Gynecological Pathology 13 259-266.

Fraser WD, Walsh CA, Birch MA, Durham B, Dillon JP, McCreavy D \& Gallagher JA 2000 Parathyroid hormonerelated protein in the aetiology of fibrous dysplasia of bone in the McCune-Albright syndrome. Clinical Endocrinology 53 621-628.

Gersell DJ \& Fulling KH 1989 Localized neurofibromatosis of the female genitourinary tract. American Journal of Surgical Pathology 13 873-878.

Gersell DJ \& King TC 1988 Papillary cystadenoma of the mesosalpinx in von Hippel-Lindau disease. American Journal of Surgical Pathology 12 145-149.

Gessl A, Freissmuth M, Czech T, Matula C, Hainfellner JA, Buchfelder M \& Vierhapper H 1994 Growth hormoneprolactin-thyrotropin-secreting pituitary adenoma in atypical McCune-Albright syndrome with functionally normal Gs $\alpha$ protein. Journal of Clinical Endocrinology and Metabolism 79 1128-1134. 
Gokalp G, Hakyemez B, Kizilkaya E \& Haholu A 2007 Myxoid neurofibromas of the breast: mammographic, sonographical and MRI appearances. British Journal of Radiology 80 e234-e237.

Gordon MD, Weilert M \& Ireland K 1996 Plexiform neurofibromatosis involving the uterine cervix, endometrium, myometrium, and ovary. Obstetrics and Gynecology 88 699-701.

Goulet-Salmon B, Berthe E, Franc S, Chanel S, GalateauSalle F, Kottler M, Mahoudeau J \& Reznik Y 2004 Prostatic neuroendocrine tumor in multiple endocrine neoplasia type 2B. Journal of Endocrinological Investigation 27 570-573.

Griebel ML, Redman JF, Kemp SF \& Elders MJ 1991 Hypertrophy of clitoral hood: presenting sign of neurofibromatosis in female child. Urology 37 337-339.

Gruber MB, Healey GB, Toguri AG \& Warren MM 1980 Papillary cystadenoma of epididymis: component of von Hippel-Lindau syndrome. Urology 16 305-306.

Güran S \& Safali M 2005 A case of neurofibromatosis and breast cancer: loss of heterozygosity of NF1 in breast cancer. Cancer Genetics and Cytogenetics 156 86-88.

Hamilton A, Sirrs S, Schmidt N \& Onrot J 1997 Anaesthesia for phaeochromocytoma in pregnancy. Canadian Journal of Anaesthesia 44 654-657.

Handley J, Carson D, Sloan J, Walsh M, Thornton C, Hadden D \& Bingham EA 1992 Multiple lentigines, myxoid tumours and endocrine overactivity; four cases of Carney's complex. British Journal of Dermatology 126 367-371.

Hassan A, Bennet A, Bhalla S, Ylagan LR, Mutch D \& Dehner LP 2003 Paraganglioma of the vagina: report of a case, including immunohistochemical and ultrastructural findings. International Journal of Gynecological Pathology 22 404-406.

Higgins RV \& Hisley JC 1988 Primary hyperparathyroidism in pregnancy. A report of two cases. Journal of Reproductive Medicine 33 726-730.

Honda M, Tsukada T, Horiuchi T, Tanaka R, Yamaguchi K, Obara T, Miyakawa H, Yamaji T \& Ishibashi M 2004 Primary hyperparathyroidism associatiated with aldosterone-producing adrenocortical adenoma and breast cancer: relation to MEN1 gene. Internal Medicine $\mathbf{4 3}$ 310-314.

Hopkins PM, Macdonald R \& Lyons G 1989 Caesarean section at 27 weeks gestation with removal of phaeochromocytoma. British Journal of Anaesthesia $\mathbf{6 3}$ 121-124.

Horyn G, Bourgeois-Dujols P, Palaric JC \& Giraud JR 1988 Recklinghausen's disease and vascular complications during pregnancy. Journal de Gynecologie, Obstetrique et Biologie de la Reproduction 17 641-645.

Hsieh YY, Chang CC, Tsai HD, Yang TC, Chiu TH \& Tsai CH 1998 Primary hyperparathyroidism in pregnancy - report of 3 cases. Archives of Gynecology and Obstetrics $\mathbf{2 6 1}$ 209-214.
Huston TL \& Simmons RM 2004 Ductal carcinoma in situ in a 27-year-old woman with McCune-Albright syndrome. Breast Journal 10 440-442.

Ikota H, Tanimoto A, Komatsu H, Ozawa Y \& Matsushita H 2004 Ureteral leiomyoma causing hydronephrosis in type 1 multiple endocrine neoplasia. Pathology International 54 457-459.

Invernizzi R, Martinelli B \& Pinotti G 2008 Association of GIST, breast cancer and schwannoma in a 60-year-old woman affected by type-1 von Recklinghausen's neurofibromatosis. Tumori 94 126-128.

Joffe D, Robbins R \& Benjamin A 1993 Caesarean section and phaeochromocytoma resection in a patient with Von Hippel-Lindau disease. Canadian Journal of Anaesthesia 40 870-874.

Kajitani T, Liu S, Maruyama T, Uchida H, Sakurai R, Masuda H, Nagashima T, Ono M, Arase T \& Yoshimura Y 2008 Analysis of serum FSH bioactivity in a patient with an FSH-secreting pituitary microadenoma and multicystic ovaries: a case report. Human Reproduction 23 435-439.

Kaltsas GA, Mukherjee JJ, Jenkins PJ, Satta MA, Islam N, Monson JP, Besser GM \& Grossman AB 1999 Menstrual irregularity in women with acromegaly. Journal of Clinical Endocrinology and Metabolism 84 2731-2735.

Kariya N, Nishi S, Hosono Y, Hamaoka N, Nishikawa K \& Asada A 2005 Cesarean section at 28 weeks' gestation with resection of pheochromocytoma: perioperative antihypertensive management. Journal of Clinical Anesthesia 17 296-299.

Kawawa Y, Okamoto Y, Oharaseki T, Takahashi K \& Kohda E 2007 Paget's disease of the breast in a woman with neurofibromatosis. Clinical Imaging 31 127-130.

Kihara M, Sugita T, Nagai Y, Saeki N, Tatsuno I \& Seki K 2006 Ovarian hyperstimulation caused by gonadotroph cell adenoma: a case report and review of the literature. Gynecological Endocrinology 22 110-113.

Kleymenova E, Everitt JI, Pluta L, Portis M, Gnarra JR \& Walker CL 2004 Susceptibility to vascular neoplasms but no increased susceptibility to renal carcinogenesis in Vhl knockout mice. Carcinogenesis 25 309-315.

Kodama H, Iihara M, Okamoto T \& Obara T 2007 Waterclear cell parathyroid adenoma causing primary hyperparathyroidism in a patient with neurofibromatosis type 1: report of a case. Surgery Today 37 884-887.

Kuscu E, Oktem M, Eroglu D, Haberal A, Bilezikci B \& Demirhan B 2005 Pelvic retroperitoneal paraganglioma mimicking an ovarian mass. European Journal of Gynaecological Oncology 26 219-220.

Laven JS, Lumbroso S, Sultan C \& Fauser BC 2004 Management of infertility in a patient presenting with ovarian dysfunction and McCune-Albright syndrome. Journal of Clinical Endocrinology and Metabolism 89 1076-1078.

Lavoué V, Morcel K, Bouchard P, Sultan C, Massart C, Grall JY, Lumbroso S \& Laurent MC 2008 Restoration 
of ovulation after unilateral ovariectomy in a woman with McCune-Albright syndrome: a case report. European Journal of Endocrinology 158 131-134.

Lefevre H, Bouvattier C, Lahlou N, Adamsbaum C, Bougnères P \& Carel JC 2006 Prepubertal gynecomastia in Peutz-Jeghers syndrome: incomplete penetrance in a familial case and management with an aromatase inhibitor. European Journal of Endocrinology 154 221-227.

Lima JB \& Smith PD 1971 Sipple's syndrome (pheochromocytoma and thyroid carcinoma) with bilateral breast carcinoma. American Journal of Surgery 121 732-735.

Lindsay JR \& Nieman LK 2005 The hypothalamic-pituitaryadrenal axis in pregnancy: challenges in disease detection and treatment. Endocrine Reviews 26 775-799.

Lipper S, Willson CF \& Copeland KC 1981 Pseudogynecomastia due to neurofibromatosis - a light microscopic and ultrastructural study. Human Pathology 12 755-759.

Lisewski D, Ryan S, Lim EM, Frost F \& Nguyen H 2006 Concomitant compostite adrenal phoechromocytoma, multipte gastric stromal tumours and pseudohermaphrodism in a patient with von Recklinghausen's disease. International Seminars in Surgical Oncology 311.

Loffler KA, Biondi CA, Gartside M, Waring P, Stark M, Serewko-Auret MM, Muller HK, Hayward NK \& Kay GF 2007 Broad tumor spectrum in a mouse model of multiple endocrine neoplasia type 1. International Journal of Cancer 120 259-267.

De Luca F, Mitchell V, Wasniewska M, Arrigo T, Messina MF, Valenzise M, de Sanctis L \& Lahlou N 2008 Regulation of spermatogenesis in McCune-Albright syndrome: lessons from a 15-year follow-up. European Journal of Endocrinology 158 921-927.

Malas S, Krawitz HE, Sur RK, Uijs RR, Nayler SJ \& Levin CV 1995 Von Recklinghausen's disease associated with a primary malignant schwannoma of the breast. Journal of Surgical Oncology 59 273-275.

Martin KA, Chang RJ, Ehrmann DA, Ibanez L, Lobo RA, Rosenfield RL, Shapiro J, Montori VM \& Swiglo BA 2008 Evaluation and treatment of hirsutism in premenopausal women: an endocrine society clinical practice guideline. Journal of Clinical Endocrinology and Metabolism 93 1105-1120.

Maruyama T, Masuda H, Uchida H, Nagashima T \& Yoshimura Y 2005 Follicle stimulating hormone-secreting pituitary microadenoma with fluctuating levels of ovarian hyperstimulation. Obstetrics and Gynecology 105 1215-1218.

Matarazzo P, Lala R, Andreo M, Einaudi S, Altare F, Viora E, Buzi F, De Luca F, De Sanctis V, Rigon F et al. 2006 McCune-Albright syndrome: persistence of autonomous ovarian hyperfunction during adolescence and early adult age. Journal of Pediatric Endocrinology \& Metabolism 19 607-617.

McCluggage WG \& Young RH 2006 Paraganglioma of the ovary: report of three cases of a rare ovarian neoplasm, including two exhibiting inhibin positivity. American Journal of Surgical Pathology 30 600-605.
McKeeby JL, Li X, Zhuang Z, Vortmeyer AO, Huang S, Pirner M, Skarulis MC, James-Newton L, Marx SJ \& Lubensky IA 2001 Multiple leiomyomas of the esophagus, lung, and uterus in multiple endocrine neoplasia type 1. American Journal of Pathology 159 1121-1127.

Mehta GU, Shively SB, Gläsker S, Bechert CJ, Zhuang Z, Raffeld M, Lonser RR, Oldfield EH \& Vortmeyer AO 2007 von Hippel-Lindau disease: epididymal cystadenoma targeted by metastatic events. Urology 69 1209.e9-1209.e12.

Millman SL \& Mercado CL 2004 An unusual presentation of neurofibromatosis of the breast. Breast Journal 10 45-47.

Murat A, Kansiz F, Kabakus N, Kazez A \& Ozercan R 2004 Neurofibroma of the breast in a boy with neurofibromatosis type 1. Clinical Imaging 28 415-417.

Murayama Y, Yamamoto Y, Shimojima N, Takahara T, Kikuchi K, Iida S \& Kondo Y 1999 T1 breast cancer associated with Von Recklinghausen's neurofibromatosis. Breast Cancer 6 227-230.

Murgia A, Martella M, Vinanzi C, Polli R, Perilongo G \& Opocher G 2000 Somatic mosaicism in von HippelLindau disease. Human Mutation 15114.

Nabhan ZM, West KW \& Eugster EA 2007 Oophorectomy in McCune-Albright syndrome: a case of mistaken identity. Journal of Pediatric Surgery 42 1578-1583.

Nakamura M, Tangoku A, Kusanagi H, Oka M \& Suzuki T 1998 Breast cancer associated with Recklinghausen's disease: report of a case. Nippon Geka Hokan 67 3-9.

Natsiopoulos I, Chatzichristou A, Stratis I, Skordalaki A \& Makrantonakis N 2007 Metaplastic breast carcinoma in a patient with Von Recklinghausen's disease. Clinical Breast Cancer 7 573-575.

Ni Y, Zbuk KM, Sadler T, Patocs A, Lobo G, Edelman E, Platzer P, Orloff MS, Waite KA \& Eng C 2008 Germline mutations and variants in the succinate dehydrogenase genes in Cowden and Cowden-like syndromes. American Journal of Human Genetics 83 261-268.

Nicolaij D, Vogel-Kerebyn C, van den Bergh R \& Steeno OP 1979 Bilateral epididymal cysts as the first clinical manifestation of von Hippel-Lindau-disease. A case report. Andrologia 11 234-235.

Nortier J, Noel JC, Verhest A, Van Gansbeke D \& Sternon J 1989 Abdominal localizations of von Recklinghausen's neurofibromatosis: apropos of a false uterine leiomyosarcoma. Revue Médicale de Bruxelles 10 281-289.

Nozawa A, Saitoh T, Satoh S \& Nakatani Y 2004 A case of MEN IIA variant associated with ectopic ACTH production and mammary carcinoma. Nippon Rinsho 62 967-971 (medline abstract).

Nunes TF, Costa RP \& Navarro FC 2005 Von Recklinghausen's disease with urogenital manifestation. International Brazilian Journal of Urology 31 153-154.

Nwokoro NA, Korytkowski MT, Rose S, Gorin MB, Penles Stadler M, Witchel SF \& Mulvihill JJ 1997 Spectrum of malignancy and premalignancy in Carney syndrome. American Journal of Medical Genetics 73 369-377. 
Pal SK, Blazer K, Weitzel J \& Somlo G 2009 An association between invasive breast cancer and familial idiopathic hyperparathyroidism: a case series and review of the literature. Breast Cancer Research and Treatment 115 $1-5$.

Papageorgiou T \& Stratakis CA 2002 Ovarian tumors associated with multiple endocrine neoplasias and related syndromes (Carney complex, Peutz-Jeghers syndrome, von Hippel-Lindau disease, Cowden's disease). International Journal of Gynecological Cancer 12 337-347.

Paris PL, Sridharan S, Hittelman AB, Kobayashi Y, Perner S, Huang G, Simko J, Carroll P, Rubin MA \& Collins C 2009 An oncogenic role for the multiple endocrine neoplasia type 1 gene in prostate cancer. Prostate Cancer and Prostatic Diseases 12 184-191.

Pellegata NS, Quintanilla-Martinez L, Siggelkow H, Samson E, Bink K, Höfler H, Fend F, Graw J \& Atkinson MJ 2006 Germ-line mutations in p27Kip1 cause a multiple endocrine neoplasia syndrome in rats and humans. PNAS 103 15558-15563.

Pieringer H, Hatzl-Griesenhofer M, Shebl O, WiesingerEidenberger G, Maschek W \& Biesenbach G 2007 Hypocalcemic tetany in the newborn as a manifestation of unrecognized maternal primary hyperparathyroidism. Wiener Klinische Wochenschrift 119 129-131.

Prowse AH, Webster AR, Richards FM, Richard S, Olschwang S, Resche F, Affara NA \& Maher ER 1997 Somatic inactivation of the VHL gene in Von HippelLindau disease tumors. American Journal of Human Genetics 60 765-771.

Rey RA, Venara M, Coutant R, Trabut JB, Rouleau S, Lahlou N, Sultan C, Limal JM, Picard JY \& Lumbroso S 2006 Unexpected mosaicism of R201H-GNAS1 mutant-bearing cells in the testes underlie macro-orchidism without sexual precocity in McCune-Albright syndrome. Human Molecular Genetics 15 3538-3543.

Riminucci M, Collins MT, Lala R, Corsi A, Matarazzo P, Gehron Robey P \& Bianco P 2002 An R201H activating mutation of the GNAS1 (Gs $\alpha$ ) gene in a corticotroph pituitary adenoma. Molecular Pathology 55 58-60.

Ronchese F 1953 Neurofibromatosis and adenocarcinoma of (male) breast. A. M. A. Archives of Dermatology and Syphilology 68359.

De Sanctis C, Lala R, Matarazzo P, Andreo M \& de Sanctis L 2003 Pubertal development in patients with McCuneAlbright syndrome or pseudohypoparathyroidism. Journal of Pediatric Endocrinology \& Metabolism 16 293-296.

Scheithauer BW, Kovacs K, Nose V, Lombardero M, Osamura YR, Lloyd RV, Horvath E, Pagenstecher A, Bohl JE \& Tews DS 2009 Multiple endocrine neoplasia type 1-associated thyrotropin-producing pituitary carcinoma: report of a probable de novo example. Human Pathology 40 270-278.

Scheper MA, Nikitakis NG, Sarlani E, Sauk JJ \& Meiller TF 2006 Cowden syndrome: report of a case with immunohistochemical analysis and review of the literature. Oral Surgery, Oral Medicine, Oral Pathology, Oral Radiology, and Endodontics 101 625-631.

Schmidt H \& Kiess W 1998 Secondary central precocious puberty in a girl with McCune-Albright syndrome responds to treatment with $\mathrm{GnRH}$ analogue.

Journal of Pediatric Endocrinology \& Metabolism 11 77-81.

Schnatz PF \& Thaxton S 2005 Parathyroidectomy in the third trimester of pregnancy. Obstetrical and Gynecological Survey 60 672-682.

Schrager CA, Schneider D, Gruener AC, Tsou HC \& Peacocke M 1998 Clinical and pathological features of breast disease in Cowden's syndrome: an underrecognized syndrome with an increased risk of breast cancer. Human Pathology 29 47-53.

Sharif S, Moran A, Huson SM, Iddenden R, Shenton A, Howard E \& Evans DG 2007 Women with neurofibromatosis 1 are at a moderately increased risk of developing breast cancer and should be considered for early screening. Journal of Medical Genetics 44 481-484.

Sharma JB, Wadhwa L, Malhotra M, Arora R, Garg A \& Singh S 2004 Huge localized vaginal neurofibromatosis: an unusual cause of postmenopausal bleeding. Journal of Obstetrics and Gynaecology Research 30 96-99.

Shen T, Zhuang Z, Gersell DJ \& Tavassoli FA 2000 Allelic deletion of VHL gene detected in papillary tumors of the broad ligament, epididymis, and retroperitoneum in von Hippel-Lindau disease patients. International Journal of Surgical Pathology 8 207-212.

Sherman JE \& Smith JW 1981 Neurofibromas of the breast and nipple-areolar area. Annals of Plastic Surgery 7 302-307.

Shimon I, Rubinek T, Bar-Hava I, Nass D, Hadani M, Amsterdam A \& Harel G 2001 Ovarian hyperstimulation without elevated serum estradiol associated with pure follicle-stimulating hormone-secreting pituitary adenoma. Journal of Clinical Endocrinology and Metabolism 86 3635-3640.

Socin HV, Chanson P, Delemer B, Tabarin A, Rohmer V, Mockel J, Stevenaert A \& Beckers A 2003 The changing spectrum of TSH-secreting pituitary adenomas: diagnosis and management in 43 patients. European Journal of Endocrinology 148 433-442.

Solh HM, Azoury RS \& Najjar SS 1983 Peutz-Jeghers syndrome associated with precocious puberty. Journal of Pediatrics 103 593-595.

Sourvinos G, Miyakis S, Liloglou TL, Field JK \& Spandidos DA 2001 Von Hippel-Lindau tumour suppressor gene is not involved in sporadic human breast cancer. Tumour Biology 22 131-136.

Stratakis CA, Papageorgiou T, Premkumar A, Pack S, Kirschner LS, Taymans SE, Zhuang Z, Oelkers WH \& Carney JA 2000 Ovarian lesions in Carney complex: clinical 
genetics and possible predisposition to malignancy. Journal of Clinical Endocrinology and Metabolism 85 4359-4366.

Stratakis CA, Kirschner LS \& Carney JA 2001 Clinical and molecular features of the Carney complex: diagnostic criteria and recommendations for patient evaluation. Journal of Clinical Endocrinology and Metabolism 86 4041-4046.

Sutphen R, Galán-Goméz E \& Kousseff BG 1995 Clitoromegaly in neurofibromatosis. American Journal of Medical Genetics 55 325-330.

Sztal-Mazer S, Topliss DJ, Simpson RW, Hamblin PS, Rosenfeld JV \& McLean CA 2008 Gonadotroph adenoma in multiple endocrine neoplasia type 1. Endocrine Practice 14 592-594.

Tanabe Y, Nakahara S, Mitsuyama S, Ono M \& Toyoshima S 1998 Breast cancer in a patient with McCune-Albright syndrome. Breast Cancer 5 175-178.

Tolis G 1980 Prolactin: physiology and pathology. Hospital Practice 15 85-95.

Treilleux I, Freyer G, Tabone E, Chassagne-Clement C, Bremond A \& Bailly C 1997 Pancreatic neuroendocrine carcinoma metastatic to the breast as part of the multiple endocrine neoplasia type 1 syndrome. Endocrine Pathology 8 251-258.

Trouillas J, Labat-Moleur F, Sturm N, Kujas M, Heymann MF, Figarella-Branger D, Patey M, Mazucca M, Decullier E, Vergès B et al. 2008 Pituitary tumors and hyperplasia in multiple endocrine neoplasia type 1 syndrome (MEN1): a case-control study in a series of 77 patients versus 2509 non-MEN1 patients. American Journal of Surgical Pathology 32 534-543.

Virdis R, Sigorini M, Laiolo A, Lorenzetti E, Street ME, Villani AR, Donadio A, Pisani F, Terzi C \& Garavelli L 2000 Neurofibromatosis type 1 and precocious puberty. Journal of Pediatric Endocrinology \& Metabolism 13 (Suppl 1) 841-844.

Virdis R, Street ME, Bandello MA, Tripodi C, Donadio A, Villani AR, Cagozzi L, Garavelli L \& Bernasconi S 2003 Growth and pubertal disorders in neurofibromatosis type 1. Journal of Pediatric Endocrinology \& Metabolism 16 (Suppl 2) 289-292.

Wasniewska M, De Luca F, Bertelloni S, Matarazzo P, Weber G, Crisafulli G, Valenzise M \& Lala R 2004
Testicular microlithiasis: an unreported feature of McCune-Albright syndrome in males. Journal of Pediatrics 145 670-672.

Wasniewska M, Matarazzo P, Weber G, Russo G, Zampolli M, Salzano G, Zirilli G, Bertelloni S \& Italian Study Group for Alterations of Gs alpha Protein Function 2006 Clinical presentation of McCune-Albright syndrome in males. Journal of Pediatric Endocrinology \& Metabolism 19 (Suppl 2) 619-622.

Wei EX, Albores-Saavedra J \& Fowler MR 2005 Plexiform neurofibroma of the uterine cervix: a case report and review of the literature. Archives of Pathology \& Laboratory Medicine 129 783-786.

Whelan T, Gatfield CT, Robertson S, Carpenter B \& Schillinger JF 1995 Primary carcinoid of the prostate in conjunction with multiple endocrine neoplasia IIb in a child. Journal of Urology 153 1080-1082.

Wieacker P, Stratakis CA, Horvath A, Klose S, Nickel I \& Muschke P 2007 Male infertility as a component of Carney complex. Andrologia 39 196-197.

Wilson CH, Griffith CD, Shrimankar J \& Douglas F 2004 Gynaecomastia, neurofibromatosis and breast cancer. Breast 13 77-79.

Witten FR, O'Brien DP III, Sewell CW \& Wheatley JK 1985 Bilateral clear cell papillary cystadenoma of the epididymides presenting as infertility: an early manifestation of von Hippel-Lindau's syndrome. Journal of Urology 133 1062-1064.

Young S, Gooneratne S, Straus FH II, Zeller WP, Bulun SE \& Rosenthal IM 1995 Feminizing Sertoli cell tumors in boys with Peutz-Jeghers syndrome. American Journal of Surgical Pathology 19 50-58.

Zbar B, Kaelin W, Maher E \& Richard S 1999 Third International Meeting on von Hippel-Lindau disease. Cancer Research 59 2251-2253.

Zia MK, Rmali KA, Watkins G, Mansel RE \& Jiang WG 2007 The expression of the von Hippel-Lindau gene product and its impact on invasiveness of human breast cancer cells. International Journal of Molecular Medicine 20 605-611.

Zung A, Shoham Z, Open M, Altman Y, Dgani R \& Zadik Z 1998 Sertoli cell tumor causing precocious puberty in a girl with Peutz-Jeghers syndrome. Gynecologic Oncology 70 421-424. 